Biochemical mechanisms are being studied to determine how cell division is inhibited by radiometric compounds and an investigation is being undertaken into the biochemical composition and detoxifying function of lysozymes. A wide study of the movement of pesticides and agricultural chemicals in and over soil is being made to show how pollution of surface and ground waters is effected and how the movement may affect plants and animals in their uptake of such polluted waters. A three phase study has been completed of food-borne Salmonella infections of avian origin, and an investigation of botulism in foods has been started.

Four more projects have been proposed but still need money. One of these is the isolation of natural plant toxins and assessment of their toxicity-these toxins are mainly of academic interest, but it is surprising that no proposal has been made for work on mycotoxins, which are of some economic importance in the United States.

\section{New Zealand Science}

The New Zealand Department of Scientific and Industrial Research continues to increase the scale of its activity. According to the Annual Report for the year to March 31, 1966, just published (Government Printer, Wellington, $3 s$.), the scientific staff of the department increased by 42 to a total of 553 . The total expenditure during the year amounted to $£ 3.477$ million, more than 10 per cent of which was spent on grants to various research institutes and research associations.

In its research policy the department is hoping to give increasing attention to the problems of particular concern to the economy of New Zealand, in particular a more efficient use of labour and materials. The Institute of Nuclear Sciences, which supplies radioactive isotopes to users in New Zealand, is particularly pleased with the profit being derived in industry from the use of its materials. Prospecting for minerals continues and there has been some success in research for ilmenite, and there is a possibility that "the commercial climate" will become more favourable for the use of titanium ores in New Zealand in the years immediately ahead. Attention is also being given to the possible extension of the present use of geothermal steam at Wairakei and elsewhere. Preliminary studies for underground reservoirs have suggested that each of these may be big enough to support a geothermal power station similar to that opcrating at Wairakei. There, during the past ten years, the pressure of the hot water at the bottom of the bore holes has dropped, presumably because of the increasing rate at which stcam is being used at the power station. Although the causes of this decline in pressure are not properly understood, it is expected that it will be 70 years before the present reservoir has shrunk by as much as 10 per cent.

The department is making what use it can of parasitic insects in pest control. In the past it has proved possible to control the oak leaf miner and Mexican devil weed by such means. In the current growing season, record numbers of insects are being released to control pests. In the South Island female thynnid parasites are being released in the hope that they will control grass grub, and similar methods are being used against the ryegrass stem weevil, the potato tuber moth and the passion vine hopper.
University News:

British Columbia

Prof. J. H. QuAstel has been appointed professor of neurochemistry, in the Faculty of Medicine, and honorary professor of biochemistry.

\section{London}

THE title of professor emeritus has been conferred on the following: Prof. F. Bergol (chemistry, in respect of his former post as professor of chemistry in the Institute of Cancer Research : Royal Cancer Hospital); Prof. J. C. Buckley (helminthology, in respect of his former post as William Julien Courtauld professor of helminthology in the London School of Hygiene and Tropical Medicine); Prof. J. A. V. Butler (physical chemistry, in respect of his former post as professor of physical chemistry in the Institute of Cancer Research: Royal Cancer Hospital); Prof. G. A. H. Buttle (pharmacology, in respect of his former post as Wellcome professor of pharmacology in tho School of Pharmacy); Sir Aubrey Lewis (psychiatry, in respect of his former post as professor of psychiatry in the Institute of Psychiatry); Sir John McMichael (medicine, in respect of his former post as professor of medicine in the Postgraduate Medical School of London); Prof. C. M. White (fluid mechanics and hydraulic engineering, in respect of his former post as professor of fluid mechanics and hydraulic engineering at the Imperial College of Science and Technology); Prof. D. Williams (mining geology, in respect of his former post as professor of mining geology in the Imperial College of Science and Technology).

Pennsylvania

DR. D. White, professor of chemistry at Ohio State University, has been appointed chairman of the Department of Chemistry. Dr. J. Donohue, chairman of the Department of Chemistry in the University of Southern California, has been appointed professor of chemistry.

\section{Appointments}

Mr. J. A. RAtcliffe, director of the Radio and Space Research Station of the Science Research Council until his retirement this year, has been appointed president of the Institution of Electrical Engineers for the session 1966 67. He will take office as president as from October 1 .

DR. H. KING, scientific director of the London Planetarium, has been appointed first curator of the McLaughlin Planetarium of the Royal Ontario Museum of the University' of Toronto. Dr. King is also secretary-and a former president- of the British Astronomical Association.

Mr. M. H. Lovell has been appointed director of the British Society for International Understanding on the retirement of Mr. J. Eppstein. Mr. Eppstein, who for the past 27 years has been director, remains editor of the Society's publications.

\section{Announcements}

A commirtee of chemists closely associated with the activities of Prof. T. P. Hilditch, who died on August 9, 1965, have been eonsidering a suitable permanent tribute to his memory in the form of memorial lectures to be delivered at a frequency determined by the sum realized. All those interested aro invited to contribute to an appeal fund. A trust fund will be set up. Donations should be sent to Martins Bank, Ltd., Water Street, Liverpool 1, and made payable to the "Hilditch Memorial Fund".

THE Deutsche Akademie der Naturforscher Leopoldina recently elected the following new members in the sections indicated: Mathematics, Prof. M. Kneser (Göttingen); 